José Luis Solleiro Rebolledo

Institute of Applied Sciences and Technology, UNAM (Mexico)

Moisés Braulio García Martínez.

Autonomous University of San Luis Potosí, UCBTS (Mexico)

Rosario Castañón Ibarra

Institute of Applied Sciences and Technology, UNAM (Mexico)

Laura Elena Martínez Salvador

Institute of Social Research, UNAM (Mexico)

\title{
Smart specialization for building up a regional innovation agenda: the case of San Luis Potosí, Mexico
}

\begin{abstract}
The state of San Luis Potosí (SLP) is divided into four regions: "Altiplano, Centro, Huasteca and Media". A large socioeconomic inequality is perceived among the regions, this is especially observed when comparing Centro with the other regions, mainly because Centro region shows greater economic dynamism and has a great amount of companies, educational institutions and research centers, which contributes to lower its socioeconomic lag. In order to reduce the social inequality and the economic development gap of SLP, a project for the construction of innovation agendas with a regional focus was formulated applying RIS3 methodology.

Therefore, this article has as its main objective, to present and analyze the results of this project, through the identification of regional economic potential and their areas of smart specialization, as well as international technological trends in those areas. As an important component, a governance mechanism was organized in the four regions used to build consensus and legitimate the RIS3 process. In the framework of triple- helix participatory workshops, a portfolio of priority innovation projects was defined. This article offers an analysis of favorable factors and obstacles faced during the process; a series of recommendations for the promotion of regional innovation agendas (RIA) plus brief conclusions.
\end{abstract}

Keywords: Regional innovation system; Smart specialization; Innovation; Mexico.

Corresponding author: e-mail: laura.martinez@ sociales.unam.mx

Received 25 Oct. 2019 - Accepted 14 Dec 2019

This is an Open Access article distributed under the terms of the Creative Commons Attribution-Non-Commercial-No Derivatives License (http://creativecommons.org/licenses/by-nc-nd/4.0/), which permits non-comercial re-use and distribution, provided the original work is properly cited, and is not altered or transformed in any way. 


\section{Introduction}

Innovation is considered an important driver for regional competitiveness and development. In this sense, regional approaches to promote innovation, take increasing relevance; hence, methodologies have been created leading to the definition of region-based strategies and institutional frameworks, to enhance the effects of agglomeration as the basis for technological learning and interactive innovation (Dutrenit 2009). Within this framework, new approaches to defining innovation policies have appeared. That is the case of Research and Innovation Strategies for Smart Specialization (RIS3), a methodology created to identify the innovation potential of specific regions, in order to optimize investments and effects of innovation.

In Mexico, RIS3 methodology was implemented for the first time in 2014. The National Council for Science and Technology (CONACYT) was the promoter of the elaboration of state innovation agendas (SIA) for its 32 states. In these agendas, seen as instruments of innovation policy, the states' strategic sectors with the greatest potential were identified, and a portfolio of research, development and innovation projects was defined; these projects were considered because of their high 'multiplier effect'. In the case of San Luis Potosí (SLP), the state agenda focused on four economic sectors -food, automotive, renewable energy and logistics- all closely related to the productive vocations of the capital city, but not necessarily for the other regions, which could sharpen existing disparities, that will be described later.

Due to this situation, in 2018, the State Government of SLP highlighted the need to conducting studies of technological capabilities in its four regions, in order to develop 
innovation agendas using the RIS3 methodology. The authors of this study participated in 2019 as coordinators for the preparation of the four regional agendas.

Therefore, this study aims to analyze the process of planning and creating the agendas, recognizing the role of the main actors, the governance mechanisms, and favorable factors and obstacles of this process. Based on this analysis, conclusions and recommendations are presented to improve the building of innovation agendas (RIA) in developing regions.

This article is divided into five sections. In the first one, the review of the literature on the RIS3 approach is presented and it is used as a basis for the identification of innovation opportunities in the regions, in order to design policies and instruments for innovation.

The second section provides details on the methodology for applying the RIS3 approach, in the construction of RIAs, as well as on the type of analysis that has been carried out based on the authors' experience while directing this process.

The third section is devoted to the analysis of the application of the RIS3 methodology in the four regions of SLP. This is based on the identification of regional economic vocations and their areas of smart specialization, as well as on the recognition of the potential effects of global technological trends.

A fourth section describes the process of developing the agendas, and the governance frame used for this. The main challenges to managing this project are described and analyzed as well.

Finally, in a fifth section, a series of conclusions and recommendations for the promotion of RIAs are made. 


\section{Regional innovation systems and smart specialization}

National innovation systems (NIS) are created by the interaction of agents (companies, universities, research centers and technological institutes, supporting organizations for business activities, financial system and decision-makers), who act within institutional frameworks and policies. These NIS become conductive environments for the accumulation of knowledge and the collaboration between agents within regions (Lundvall 1992). Likewise, territorial models have been defined as Regional Innovation Systems (RIS) (Cooke 1998), in order to include innovation microsystems at different scales (Rózga and Solleiro 2017), and also taking into account that in the regions underlies the potential to build competitive capabilities through innovation. Several authors consider that a main challenge of the innovation system framework is to understand the specific challenges and potential of regions and how specific policy initiatives could foster the learning and innovation processes and induce a local development process that is dynamic and sustainable. (Cassiolato et al. 2013; Cooke et al. 1997; Barca et al. 2012).

Innovation for competitiveness in regions can be obtained through the efficient direction of resources in areas of specialization and through priority projects embodied in a regional innovation agenda (RIA) that relates to those public policy instruments that allow coordination and interaction of regional actors in a collective endeavor that goes beyond a triple helix approach (Höglund and Linton 2017), with the addition of a fourth dimension (including society, civil associations, end users or consumers) transforming the triple into a quadruple helix analytical instrument.

The RIA is created based on the identification and selection of priority areas and the definition of strategies to articulate the agents of the regional innovation system; this with the 
aim of promoting investment in sectors that can have a high impact in the economy of the region. These regions, as territorial divisions, have historical, political, geographical, and even cultural characteristics that unify them.

In order to promote innovation in the regions and investment in a rational and efficient way, approaches such as Research and Innovation Strategies for Smart Specialization (RIS3) were developed by the European Union in 2013. This methodology has a series of principles under which "each region must select a limited number of areas of activity, or knowledge, in which the region can be truly competitive in the context of an increasingly globalized economy" (Del Castilli and Paton 2013, 17). In Europe, the RIS3 Platform is designed to help in the capacity-building activities of the regions, which are essential for upgrading their institutional quality and capabilities and building their innovation agendas.

The RIS3 methodology favors the design of public policies and a better orientation of innovation investment, hinged on the productive vocations of the regions. This methodology is based on the definition of the following items (Foray et al. 2012):

1. Analysis of the regional context and the potential for innovation: at this point, a characterization of the region and analysis of the territory assets are carried out.

2. Governance is understood as different coordination mechanisms in which actors, located normally outside of governmental sphere, can influence the regional decisionmaking process to improve regional development.

3. Development of a collective vision for the future of the region: this step implies the development of a shared vision of economic development as the main driver of strategic projects. This vision should be realistic and bold enough to align different socioeconomic actors 
4. Identification of priorities: At this point, an identification of priority sectors with potential for specialization, growth or diversification is carried out as the base for building a portfolio of innovation projects.

5. Definition of coherent mixed policies and building up of an innovation agenda.

6. Integration of evaluation and monitoring mechanisms.

In terms of governance, analysis of experience in European regions show that not all institutional and governance arrangements are necessarily fixed and one of the advantages of the RIS3 agenda may be precisely the fact that the process opens opportunities to adapt institutional and governance arrangements for better policy alignment were explicitly acknowledged (Kroll 2015). Indeed, any outcome-oriented reshaping of local and regional governance in response to the RIS3 consultation and public participation processes may prove to be a genuine long run benefit of such approaches (Kroll 2015).

Although there is a great discussion about the elements that define governance (Abas 2019; Graham et al., 2003; Perry and May 2007), there is also consensus that sound governance structures in regional innovation system must be created, putting emphasis on institutional arrangements to designing, supporting and implementing innovation policies (Flanagan et al. 2011; Morisson and Doussineau 2019). Such governance structure enhances the inclusion of actors that do not participate regularly in the decision-making process, thus generating participatory spaces for knowledge exchange, advocacy and social change.

In Latin America, besides Mexico, there are some experiences in applying RIS3. Barroeta et al. (2017) analyzed different experiences and made following SWOT analysis. 
Table 1. SWOT analysis of regional specialization in Latin-America

\begin{tabular}{|c|c|}
\hline Strengths & Opportunities \\
\hline $\begin{array}{l}\text { National development policies focused on innovation } \\
\text { exist. } \\
\text { Several countries are facilitating regional specialization } \\
\text { (pilot, demonstration effect). } \\
\text { Extensive knowledge of the European RIS } 3 \text { strategies } \\
\text { among the persona responsible for innovation policy. } \\
\text { Significant number of companies and capacities in sectors } \\
\text { related to creative industries and the ICTs }\end{array}$ & $\begin{array}{l}\text { Existence of National research systems } \\
\text { Specialization sectors have been identified at a national or } \\
\text { regional level } \\
\text { Traditional industries with reconversion potential towards } \\
\text { new sectors } \\
\text { New policies for the decentralization of resources and } \\
\text { their applicability of the RIS for all of the regional and } \\
\text { local development policies } \\
\text { Existences of large companies as a tractor effect of global } \\
\text { value chains with potential local impact }\end{array}$ \\
\hline Weaknesses & Threats \\
\hline $\begin{array}{l}\text { Highly centralized systems } \\
\text { Limited financial resources oriented to support related } \\
\text { action } \\
\text { Little interaction between universities, research centers } \\
\text { and companies } \\
\text { Limited evaluation systems and indicators applied on a } \\
\text { regional scale } \\
\text { Persistent technology gaps and limited business } \\
\text { innovation } \\
\text { Little inter-regional cooperation in technology } \\
\text { Lack of technological centers operating at a Latina } \\
\text { American Scale }\end{array}$ & $\begin{array}{l}\text { The weakness of the tax system and the global crisis } \\
\text { reduce the incentives to execute innovation strategies } \\
\text { Conformism with specialization applied exclusively to } \\
\text { extractive and agricultural sectors } \\
\text { High territorial concentration of resources and capacities } \\
\text { (e.g. metropolitan zones and/or logistic corridors) } \\
\text { The weakening of the new regional integration processes }\end{array}$ \\
\hline
\end{tabular}

Source: Barroeta et al. $(2017,30)$

The main difficulties for RIS3 implementation identified by Barroeta et al. (2017) lie in the articulation of innovation policies with other relevant policies as well as the governance of the process. Another important limitation relates to the incomplete implementation of innovation agendas due to lack of continuity in policies and programs derived from changes in central governments that concentrate most of the resources for science, technology and innovation. These non-EU-RIS3 experiences reflect an inadequate institutional capacity for fostering innovation as well as a low level of regional funding as well as financial autonomy; a limited influence of the regional authorities in the design and implementation of national public policies and a weak governance structure that does not include an adequate private actor's representation (Goméz and Dos Santos 2017). 


\section{Methodology}

The authors of this research have coordinated the creation of the RIA in the regions of SLP; this is why the methodological approach used is based on Action Research, a process of evaluation that enables learning by doing, as researchers and practitioners work alongside one another.

This analytical framework establishes that researchers of the phenomenon are not set aside from the phenomenon itself; this is achieved through diagnosing the problem, proposing new approaches, suggesting hypotheses and evaluating the changes resulting from the intervention (Checkland 1999; Lewin 1958). The essence of action research is that the researcher does not become an outsider and brings together a range of multiphase stakeholders to inclusively share knowledge to find solutions to social problems while considering the local context (Morchain et al. 2019).

According to Lewin (1958) there are three most important characteristics of modern action research which are: participatory nature, democratic impulse and simultaneous contribution to knowledge in the social sciences. Considering this framework, the authors of this research have actively participated in the process of building up the RIA, following guidelines of the Soft Systems methodology developed by Checkland and seeking to articulate a continuous learning process to address a situation in which there is a high social, political and human component. This distinguishes Soft System from other methodologies that deal with hard problems, with a more quantitative orientation. Using this approach of complex systems, it is possible to take advantage of its characteristics for the interpretation and analysis of innovation ecosystem of specific regions, just as it has been developed by several 
evolutionary economists to explain the dynamics of productive systems (Silverberg, Dosi, and Orsenigo 1988; Foster 1993 and 2005; Safarzynska and Van den Bergh 2010).

Despite the usefulness that action-research tool might represent, it is important to stablish that some subjectivity could be faced during the systematization and analysis of any experience. To reduce the risk of that subjectivity, authors of this paper have implemented frequent discussions with stakeholders in the region as well as reporting to the main user of the study, putting emphasis on verifying judgements and assessments with relevant actors of the policymaking process. With this practice, action-research generates a spiral of knowledge and feedback.

The creation of regional agendas began with the identification of relevant actors in the four regions of SLP, this, in order to recognize the innovation ecosystem and its potential, and to be able to integrate an Advisory Council in each region, which is a critical element of the governance required for the process to be legitimate and to continuously count on public support once the definition of the agenda is finished. In previous years (CONACYT 2015), it was confirmed that the best way to go on the creation of RIA was to build up a governance proposal that incorporates representatives of industry, academia and government as well as some opinion leaders. The integration of the advisory councils of each region ${ }^{1}$ was settled in coordination with SLP's Council of Science and Technology authorities (COPOCyT for its

\footnotetext{
${ }^{1}$ It was suggested that the Councils should have the following functions:

a) Support to establish relationships with various stakeholders of the strategic sectors for the development of the state and the region.

b) Feedback on the diagnosis of the socioeconomic situation of the regions and the findings reached in the project in terms of project identification, existing innovation capabilities, selection of priority sectors and specialization niches.

c) Support through their experience and expert judgment for the elaboration of policy and strategy recommendations for the research and technological development projects identified in the strategic sectors.

d) Guidance on the best modality to present the results so that they are accepted by the decision-makers in the relevant institutions of the state and the country.
} 
acronym in Spanish), trying to maintain a balance between the members of above-mentioned sectors in each region.

At the same time, in order to have enough information to recognize regional productive vocations and viable opportunities for innovation, a diagnostic document was made considering sociodemographic, economic, and scientific-technological and innovation capabilities of each of the four regions of the state. For this purpose, the following actions were carried out:

- An analysis of the economic variables to identify the strategic economic activities in each region.

- An analysis of the relevant public policies and instruments used for the development of research and innovation activities in the state.

- A characterization of the scientific and technological capacities in the regions through an analysis of firms, higher education institutions, research centers and other organizations of the innovation ecosystem.

These documents were central to identify specialization areas for each region; these papers were discussed and approved by COPOCyT and the Advisory Council, in order to decide on the smart specialization areas to be considered in each region.

Once the strategic sectors of the regions were identified, an analysis of technological trends was carried out to identify future scenarios with potential impact on these sectors. These technological trends were studied based on scientific literature and patents. The information generated (socio-economic studies, determination of smart specialization profiles, map of actors in the innovation ecosystem, determination of priority sectors, and analysis of technological trends) was shared with many different persons who 
were invited to participate in consultation workshops to elaborate the regional agendas. This field work was integrated by the following activities:

- For each of the strategic sectors identified, in each of the four regions, a consultation workshop was organized convening members of the academic, business and government sectors.

- Visits to innovative firms and research institutions related to priority sectors, to get their views on relevant projects to improve sector's performance as well as their willingness to participate in those projects.

- Interviews with opinion leaders from relevant industries, state and municipal government authorities, focused on knowing their vision on development priorities, innovation potential and the main obstacles to regional development.

In consultation workshops, a synthesis of regional documents and technological trends were presented and used as information base, to conduct discussions aimed at identifying and prioritizing innovations needed to solve sector's problems and to meet market opportunities. The result was the definition of a catalog of $R \& D$ and innovation projects for the priority sectors of each region. This catalog was presented to the authorities, as well as to members of each regional Advisory Council in order to validate it. Feedback was positive and some adjustments and details for improving the catalog were recommended.

To integrate the regional agendas, for each project was prepared a document, which included objectives, justification, implementation and funding strategy. Additionally, a road map was drawn up to indicate the steps to follow to execute the project, highlighting the recommendation of participants (firms and institutions), sources of funding and other 
resources for project implementation, and the monitoring and evaluation mechanisms required for COPOCyT, as the coordinator of this initiative.

\section{Regional innovation and smart specialization agendas in the state of SLP}

San Luis Potosi is a state located at the center of Mexico and is considered a very important logistic node given its potential to connect the region (by highways, rails or secondary roads) with large cities such as Monterrey and border metropolis like Brownsville, McAllen and Laredo. SLP is connected to west states such as Veracruz and Tampico; and is very close to Mexico City (Mejía et al. 2019).

The state of SLP is divided into four regions (Altiplano, Centro, Huasteca and Media) (IIL, 2016) and contributes with $2.1 \%$ to the national gross domestic product (INEGI 2018). The state's manufacturing exports (especially of transport equipment, machinery and electronics equipment, plastics, rubber, and food products) have placed it as the 11th exporter in the country (PROMÉXICO 2017). In 2018, SLP had a population of more than 2.8 million people (2.3 percent of the total population of Mexico).

In recent years, SLP has shown economic growth mostly driven by the interest of multinational companies in the automotive sector to locate their factories in the state; this has created a sophisticated supply chain. In addition, some other consolidated activities are found in the center region such as auto parts manufacturing, agriculture and livestock production, logistics, tourism and mining.

However, among regions there is a great economic and social inequality, which is quite evident when comparing center with other regions, since center region shows greater economic dynamism and a much larger presence of firms, educational institutions and research centers (Mejia et al. 2019). So, to reduce social inequality and the economic 
development gap between SLPs regions, an initiative was created to build up the already mentioned regional innovation agendas, by following the RIS3 approach described in the previous section.

Analysis of the regional context in SLP

This section presents some economic, social, educational and technological aspects of the four regions in SLP; in table 1 a list of the most representatives institutes in SLP regions is presented, this information is relevant in order to analyze the strengths and weaknesses found in each region considering their economic sectors.

\section{Centro region (center region)}

The Center region in SLP has 11 municipalities; the state capital is located there and is characterized for having the highest contribution to the state's GDP, as well as for being the most densely populated region. It is also the most important economic node, due to the presence of national and international companies, the concentration of universities and research centers, several firms and multiple support organizations (Mejia et al. 2019). In this region, the automotive, food, manufacturing equipment, electronic and mining industry have boosted job creation (Government of San Luis Potosi 2012). Another sector that has had a considerable growth due to business and recreational activities development, is tourism.

In this region, the presence of innovative key actors is vast, the region has more than 80 educational institutions; 10 research centers; more than fifty thousand firms; medical, logistic and automotive clusters; 15 industrial areas, 25 government offices, federal and state councils, 7 chambers of commerce and various civil associations (Mejia et al. 2019, 105). 


\section{Altiplano region}

This region has 15 municipalities and is considered as a strategic point for communication between the state capital and the northern states of the country. In this region, the mining and auto parts industry are important, but also the agri-food and textile industries. Protected agriculture has been showing a significant growth, both in hectares and in production units. Livestock activity is also important since its production of goat and sheep is high (SIAP 2018).

In this region, the presence of innovative key actors is limited since in the academic sphere there are only 10 educational institutions (college education) and only one research center. This region has approximately eight thousand firms, one industrial zone, 17 government entities (that may participate in technological development and innovation) and 5 chambers of commerce and associations (Mejia et al. 2019, 152).

\section{Huasteca region}

The Huasteca region has 20 municipalities and is considered a region with a predominantly agricultural and agro industrial productive vocation, especially since it has significant production of sugar, citrus, tomato and peppers; on the other hand, livestock activity in the region is also important. Environmental conditions in Huasteca are characterized for being mostly tropical, rainy and having constant rainfall and extensive bodies of water. This has created eco-tourism activities in the zone that have grown in importance.

The area known as the 'Huasteca Potosina' is part of the Sierra Madre Oriental, an orography condition that has hindered economic integration and communications with the other regions. In this region there are 20 colleges, approximately 14,000 companies and two industrial zones (located in Ciudad Valles and Ébano). In this region there are 6 
chambers of commerce and associations, as well as 26 government entities related to the promotion of industrial, economic and innovation development (Mejia et al. 2019, 277).

\section{Media region (middle region)}

Finally, the middle region, like the Huasteca, has a productive vocation due to the food industry, as well as the agricultural sector by producing seasonal orange, green chili pepper, tomato and cattle.

In this region there are some food producing and packing companies, and protected agriculture is just entering into practice. On the other hand, tourism is an activity of great importance for the region, although it faces a pollution problem that has to do with uncontrolled exploitation of recreational spaces.

Non-metallic mining is another activity of importance for the region, although most mining producers are small companies integrated to the construction value chain as suppliers of raw materials.

In this region, actors of innovation are scarce since it has only 4 higher education institutions and less than eight thousand firms, most of them from the food industry; 25 government entities are involved in economic development, science, technology and innovation activities (Mejia et al. 2019, 204). 
Table 2. Most representative higher education and research institutions in SLP regions

\begin{tabular}{|c|c|c|}
\hline \multicolumn{3}{|c|}{ CENTER } \\
\hline $\begin{array}{c}\text { Regional main } \\
\text { economic activitiy }\end{array}$ & Higher Education center and research centers & Industrial groups and firms \\
\hline $\begin{array}{ll}\text { - } & \text { Automotive } \\
\text { industry } \\
\text { - } & \text { Food industry } \\
\text { - } & \text { Basic Metal } \\
\text { Industries } \\
\text { - } & \text { Manufacture of } \\
\text { accessories, } \\
\text { electrical } \\
\text { appliances and } \\
\text { electrical power } \\
\text { generation } \\
\text { equipment } \\
\end{array}$ & $\begin{array}{l}\text { Universidad Autónoma de San Luis Potosí (UASLP) } \\
\text { Colegio de Postgraduados } \\
\text { El Colegio de San Luis, AC* } \\
\text { Instituto Potosino de Investigación Científica y } \\
\text { Tecnológica, AC } \\
\text { Centro de Tecnología Avanzada (Advanced } \\
\text { Technology Center) }\end{array}$ & $\begin{array}{l}\text { Iberdrola; Becton Dickinson; Caterpillar } \\
\text { L’Oreal; 3M México; A Schulman } \\
\text { Bimbo; BMW } \\
\text { Canel's; Cementos Moctezuma; Cemex; } \\
\text { Continental; Cummins; Daimler; } \\
\text { Draexlmaier; General Electric; General } \\
\text { Motors; Hyundai; Herdez; Mabe } \\
\text { Maxion Wheels de México; Mexichem; } \\
\text { Robert Bosch; Toyota }\end{array}$ \\
\hline \multicolumn{3}{|c|}{ ALTIPLANO } \\
\hline $\begin{array}{ll}- & \text { Automotive } \\
\text { industry } \\
\text { - } & \text { Food industry } \\
\text { Manufacture of } \\
\text { textile products }\end{array}$ & $\begin{array}{l}\text { - } \quad \text { Universidad Intercultural de San Luis Potosí. } \\
\text { - } \quad \text { Coordinación Académica Región Altiplano } \\
\text { (UASLP) } \\
\text { - } \quad \text { Instituto Tecnológico de Matehuala } \\
\text { - } \quad \text { Universidad de Matehuala }\end{array}$ & $\begin{array}{l}\text { Grupo industrial Yazaki } \\
\text { Grupo industrial K\&S Mexicana } \\
\text { Barcel } \\
\text { Las Sevillanas } \\
\text { Productos Medellín SA de CV } \\
\text { Minera Hochschild SA de CV } \\
\text { Minera para adelante SA de CV } \\
\text { First Majestic SA de CV } \\
\text { Minera Los lagartos } \\
\text { Minera Azteca SA de CV } \\
\text { Industrial Minera México } \\
\text { Mineras Golondrinas } \\
\text { Altiplano Gold SIlver SA de CV }\end{array}$ \\
\hline \multicolumn{3}{|c|}{ MEDIA } \\
\hline $\begin{array}{ll}\text { - } & \text { Food industry } \\
\text { - } & \text { Beverage and } \\
\text { tobacco industry } \\
\text { Metal products } \\
\text { manufacturing } \\
\text { - } \\
\text { Manufacture of } \\
\text { products based on } \\
\text { nonmetallic } \\
\text { minerals } \\
\text { - } \\
\text { Agricultural sector }\end{array}$ & $\begin{array}{ll}\text { - } & \text { Instituto Tecnológico Superior de Rioverde } \\
\text { - } & \text { Unidad Académica Multidisciplinaria Zona } \\
\text { Media (UASLP) } \\
\text { - } \quad \text { Universidad Intercultural de San Luis Potosí }\end{array}$ & $\begin{array}{l}\text { Citrofrut SA de CV } \\
\text { Agrizom, SC de RL de CV } \\
\text { Centro de Producción Santa Rita, SA de } \\
\text { CV. }\end{array}$ \\
\hline \multicolumn{3}{|c|}{ HUASTECA } \\
\hline $\begin{array}{ll}\text { - } & \text { Food industry } \\
\text { - } & \text { Retail trade } \\
\text { - } & \text { Wholesale trade } \\
\text { - } & \text { Farming }\end{array}$ & $\begin{array}{ll}\text { - } & \text { Escuela Normal de la Huasteca Potosina } \\
\text { - } & \text { Instituto de Ciencias y Estudios Superiores de } \\
& \text { San Luis Potosí } \\
\text { - } & \text { Instituto Politécnico y de Estudios Superiores de } \\
& \text { los Valles de Oxitipa } \\
\text { - } & \text { Instituto Superior Interestatal de las Huastecas } \\
\text { - } & \text { Instituto Tecnológico de Ciudad Valles } \\
\text { - } & \text { Instituto Tecnológico Superior de Ébano } \\
\text { - } & \text { Instituto Tecnológico Superior de Tamazunchale } \\
\text { - } & \text { Universidad Tamazunchale } \\
\text { - } & \text { Universidad Tangamanga } \\
\text { - } & \text { Unidad Académica Multidisciplinaria Zona } \\
& \text { Huasteca } \\
\end{array}$ & $\begin{array}{l}\text { Grupo GUSI } \\
\text { Fabricaciones y Montajes Industriales JRO } \\
\text { Granja Acuícola Integral } \\
\text { Laguna del Mante } \\
\text { La Lajilla Granja Acuícola } \\
\text { Integral } \\
\text { Piasa Ingenio Plan de } \\
\text { San Luis } \\
\text { Sociedad de Productores de } \\
\text { Vainilla Tlilixochitl }\end{array}$ \\
\hline
\end{tabular}

Note: A.C for its acronym in Spanish (civil non-profit organization)

Source: Mejia et al. 2019 


\section{Journal of Evolutionary Studies in Business}

\section{Priority sectors by region in the construction of the RIA in SLP}

The priority sectors chosen (agri- food, automotive, chemical, logistics, mining, tourism) for the construction of the RIA, were discussed and selected in collaboration with government authorities, using socioeconomic information on the regions. Also, they were agreed upon with the regional Advisory Councils based on studies on regional vocations and the vision that the government portrayed in the State Development Plan. This was critical to start the RIS3 process, however it is important to highlight that the generic description of a sector does not reveal the real productive vocation of the regions. For that reason, interaction with the Advisory Councils proved to be essential to provide additional qualitative information to determine the specialization areas based on the balance of strengths and weaknesses (table 3) of the regions. This analysis was the basis to define the innovation projects during the workshops. 


\section{Journal of Evolutionary Studies in Business}

Table 3. Strengths and weaknesses of the RIA priority sectors in the SLP regions

\begin{tabular}{|c|c|c|c|c|c|c|c|}
\hline \multicolumn{8}{|c|}{ Center Region } \\
\hline \multirow{3}{*}{ Center } & Strengths & AGRI FOODS & AUTOMOTIVE & LOGISTICS & MINING & CHEMICAL & TOURISM \\
\hline & & $\begin{array}{l}\text { Large concentration } \\
\text { of specialized } \\
\text { production } \\
\text { complexes in the } \\
\text { food industry } \\
\text { (candy, dairy } \\
\text { products) } \\
\text { Main center of food } \\
\text { transformation. }\end{array}$ & $\begin{array}{l}\text { Sector dominated by } \\
\text { TIER } 1 \text { and TIER } 2 \\
\text { companies that have } \\
\text { highly standardized } \\
\text { processes for high } \\
\text { quality. } \\
\text { Recent use of robotic } \\
\text { equipment and use of } \\
\text { sensible equipment } \\
\text { Active and } \\
\text { functioning } \\
\text { automotive cluster. } \\
\text { Strong foreign direct } \\
\text { investment in the } \\
\text { sector. }\end{array}$ & $\begin{array}{l}\text { An increment in } \\
\text { logistics operations } \\
\text { due to the arrival of } \\
\text { international } \\
\text { companies in the } \\
\text { region, especially in } \\
\text { the automotive sector. } \\
\text { Increase in the } \\
\text { operations of the } \\
\text { international airport of } \\
\text { SLP. Nuevo Laredo- } \\
\text { The Nore-Saltillo- } \\
\text { Monterrey- } \\
\text { SLP highway is } \\
\text { considered the most } \\
\text { active road of the } \\
\text { national rail network. }\end{array}$ & $\begin{array}{l}\text { This region is the one } \\
\text { with the highest } \\
\text { extraction of fluorite in } \\
\text { the country (Villa de } \\
\text { Zaragoza has more than } \\
90 \% \text { of the national } \\
\text { total production). } \\
\text { Presence of research } \\
\text { centers with an impact } \\
\text { on the mining sector. }\end{array}$ & $\begin{array}{l}\text { High concentration of } \\
\text { multinational } \\
\text { productive complexes } \\
\text { with specialization in } \\
\text { the cosmetic industry } \\
\text { and personal hygiene } \\
\text { products. }\end{array}$ & $\begin{array}{l}\text { Great } \\
\text { services, good hotel facilities } \\
\text { for congresses and } \\
\text { conventions, good venues, } \\
\text { good communication, } \\
\text { technology and } \\
\text { telecommunications coverage. } \\
\text { SLP is a city considered } \\
\text { 'cultural heritage of humanity' } \\
\text { and has tourist routes } \\
\text { Mobile applications to } \\
\text { promote state events } \\
\text { (promoted by the Ministry of } \\
\text { Tourism of the State). } \\
\text { Trained providers of hotel } \\
\text { services. }\end{array}$ \\
\hline & $\begin{array}{l}\text { Weakness } \\
\text { es }\end{array}$ & $\begin{array}{l}\text { Low supply of } \\
\text { specialized technical } \\
\text { services for the food } \\
\text { industry } \\
\text { Low number of } \\
\text { innovations }\end{array}$ & $\begin{array}{l}\text { Low level of process } \\
\text { digitalization. } \\
\text { SMEs without } \\
\text { certification } \\
\text { Low knowledge and } \\
\text { use of technologies to } \\
\text { increase the } \\
\text { competitiveness and } \\
\text { efficiency of the } \\
\text { sector (internet of } \\
\text { things, big data, data } \\
\text { mining, data } \\
\text { analytics). }\end{array}$ & $\begin{array}{l}\text { International airport } \\
\text { with exceeded } \\
\text { capacity and low } \\
\text { levels } \\
\text { competitiveness. } \\
\text { Road congestion on } \\
\text { main avenues and } \\
\text { vehicular passages. }\end{array}$ & $\begin{array}{l}\text { The mining activity has } \\
\text { bad public image } \\
\text { because it is considered } \\
\text { one of the activities } \\
\text { with the } \\
\text { greatest environmental i } \\
\text { mpact. } \\
\text { Lack of investment in } \\
\text { science, technology and } \\
\text { innovation (STI) mining } \\
\text { activities } \\
\text { Low capacity for human } \\
\text { resources training }\end{array}$ & $\begin{array}{l}\text { Disarticulated chemical } \\
\text { industry. } \\
\text { Deficient capacities for } \\
\text { the usage of new } \\
\text { ingredients and the } \\
\text { creation of new } \\
\text { formulations with added } \\
\text { value and greater } \\
\text { market value. } \\
\text { Absence } \\
\text { infrastructure to } \\
\text { perform tests of new } \\
\text { formulations and } \\
\text { products. } \\
\begin{array}{l}\text { Insufficient } \\
\text { control systems from } \\
\text { the chemical industry. }\end{array}\end{array}$ & $\begin{array}{l}\text { Absence } \\
\text { of articulation between touris } \\
\mathrm{m} \text { agencies among regions. }\end{array}$ \\
\hline
\end{tabular}

Online ISSN: 2385-7137

http://revistes.ub.edu/index.php/JESB
COPE Committee on Publication Ethics Creative Commons License 4.0@Creative 


\section{Journal of Evolutionary Studies in Business}

\begin{tabular}{|c|c|c|c|c|c|c|}
\hline \multicolumn{7}{|c|}{ Altiplano Region } \\
\hline \multirow[b]{3}{*}{$\begin{array}{l}\text { Altipla } \\
\text { no }\end{array}$} & \multirow{2}{*}{ Strengths } & AGRO FOODS & AUTOMOTIVE & LOGISTICS & MINING & TOURISM \\
\hline & & $\begin{array}{l}\text { Protected agriculture and } \\
\text { greenhouses infrastructure } \\
\text { installed. } \\
\text { High livestock of sheep and } \\
\text { goats. } \\
\text { Small processing companies } \\
\text { (dairy, mezcal) } \\
\text { Institutional capacities } \\
\text { (colleges, research centers) }\end{array}$ & $\begin{array}{l}\text { The Altiplano region } \\
\text { has the second } \\
\text { highest number of } \\
\text { firms in the } \\
\text { automotive sector. } \\
\text { Large concentration } \\
\text { of metalworking } \\
\text { companies with } \\
\text { potential for } \\
\text { integration into the } \\
\text { automotive sector. } \\
\text { Growth in the } \\
\text { installation of plants } \\
\text { in the automotive } \\
\text { sector. }\end{array}$ & $\begin{array}{l}\text { Potential of highway and } \\
\text { rail communications with } \\
\text { the north of the country } \\
\text { and with the USA. } \\
\text { Connection with the main } \\
\text { trade centers in the north of } \\
\text { the country }\end{array}$ & $\begin{array}{l}\text { High attraction of } \\
\text { foreign direct } \\
\text { investment in } \\
\text { exploration and } \\
\text { extraction projects. } \\
\text { Mining tradition and } \\
\text { community interest for } \\
\text { jobs generated by this } \\
\text { industry. activity in } \\
\text { Large araction of metallic } \\
\text { extraction } \\
\text { minerals. }\end{array}$ & $\begin{array}{l}8 \text { tourist } \\
\text { including the 'mezcal route' and the 'desert } \\
\text { route'. } \\
\text { The region has an specialized tourism } \\
\text { agency }\end{array}$ \\
\hline & Weaknesses & $\begin{array}{l}\text { Adverse agronomic } \\
\text { conditions. } \\
\text { High costs per square feet of } \\
\text { water pump. } \\
\text { Low financing level for } \\
\text { producers to transit } \\
\text { to protected agriculture and } \\
\text { greenhouses. } \\
\text { High level of staff turnover. } \\
\text { Insufficient supply } \\
\text { of infrastructure for protecte } \\
\text { d agriculture and } \\
\text { greenhouses activities. } \\
\text { High raw material costs. } \\
\text { Low linkage academia - } \\
\text { industry for strengthening } \\
\text { the livestock sector }\end{array}$ & $\begin{array}{l}\text { High staff turnover } \\
\text { and low retention of } \\
\text { trained personnel. } \\
\text { Low knowledge and } \\
\text { use of technologies } \\
\text { to increase the } \\
\text { competitiveness and } \\
\text { efficiency of the } \\
\text { sector (industry 4.0, } \\
\text { advanced } \\
\text { manufacturing). }\end{array}$ & $\begin{array}{l}\text { Messy urban and industrial } \\
\text { growth that has resulted in } \\
\text { insufficient road and rail } \\
\text { infrastructure. Lack of } \\
\text { Logistics capabilities and } \\
\text { platforms. } \\
\text { Low use of technologies } \\
\text { linked to industry } 4.0 \\
\text { (sensors, information } \\
\text { systems, autonomous } \\
\text { vehicles, automated } \\
\begin{array}{l}\text { warehouses, intelligent } \\
\text { guides and } \\
\text { radiofrequency). }\end{array}\end{array}$ & $\begin{array}{l}\text { The income resulting } \\
\text { from extraction } \\
\text { activities is not } \\
\text { retained in the region. } \\
\text { The region does not } \\
\text { have companies } \\
\text { focused on the } \\
\text { maintenance of } \\
\text { equipment and tools } \\
\text { used in mining. } \\
\text { Mining companies of } \\
\text { medium and small size } \\
\text { lack preventive or } \\
\text { corrective maintenance } \\
\text { systems. } \\
\text { The mining activity } \\
\text { does not have a good } \\
\text { public image because } \\
\text { it is considered one of } \\
\text { the most polluting } \\
\text { activities. } \\
\text { Insufficient capacity } \\
\text { building CTI. }\end{array}$ & $\begin{array}{l}\text { Insufficient road and communications } \\
\text { infrastructure. } \\
\text { Tourism concentrated only in zones } \\
\text { called "anchors" like Real de Catorce. } \\
\text { Low diffusion of the tourist attractions of } \\
\text { the region. } \\
\text { Low use of Information and communication } \\
\text { technologies (ICT) for tourism services. } \\
\text { San Luis-Matehuala highway is considered } \\
\text { one of the most dangerous in the state. } \\
\text { Lack of qualified human resources for } \\
\text { tourism. }\end{array}$ \\
\hline
\end{tabular}

Online ISSN: 2385-7137

http://revistes.ub.edu/index.php/JESB
COPE Committee on Publication Ethics

Creative Commons License 4.0@creative 


\section{Journal of Evolutionary Studies in Business}

\begin{tabular}{|c|c|c|c|c|c|}
\hline \multicolumn{6}{|c|}{ Huasteca Region } \\
\hline \multirow{3}{*}{$\begin{array}{l}\text { Huaste } \\
\text { ca }\end{array}$} & \multirow[t]{2}{*}{ Strengths } & \multicolumn{2}{|l|}{ AGRO FOODS } & \multicolumn{2}{|r|}{ TOURISM } \\
\hline & & \multicolumn{2}{|c|}{$\begin{array}{l}\text { State government initiatives to boost the diversification of crops } \\
\text { with greater market value. } \\
\text { Existence of agribusiness companies } \\
\text { Important citrus production } \\
\text { State strategic programs that promote the production of market } \\
\text { value crops such as vanilla. } \\
\text { Region with the highest production of brown sugar at the national } \\
\text { level, }\end{array}$} & \multicolumn{2}{|c|}{$\begin{array}{l}\text { Municipalities of Xilitla and Tamasopo named 'Pueblos mágicos', which constitutes an } \\
\text { intangible asset for tourism. } \\
\text { Presence of trained tour operators. } \\
\text { Adventure tourism activities. } \\
\text { Tamuín local airport started operations in August } 2019 .\end{array}$} \\
\hline & $\begin{array}{l}\text { Weakness } \\
\text { es }\end{array}$ & \multicolumn{2}{|c|}{$\begin{array}{l}\text { Low level of technification in agro production and poor quality, } \\
\text { hygiene and safety systems. } \\
\text { Large losses due to postharvest handling deficiencies. } \\
\text { Inadequate water resource management. }\end{array}$} & \multicolumn{2}{|c|}{$\begin{array}{l}\text { Insufficient road and communications infrastructure. } \\
\text { Hotel services are deficient } \\
\text { Under use of ICTs. } \\
\text { Lack of connection between tourism operators. } \\
\text { Tourist facilities with low hygiene conditions. } \\
\text { Pollution of water bodies due to poor tourism practices } \\
\text { Low training of qualified human resources }\end{array}$} \\
\hline \multicolumn{6}{|c|}{ Media Region } \\
\hline \multirow[b]{3}{*}{ Media } & & AGRO FOODS & & MINING & TOURISM \\
\hline & Strengths & $\begin{array}{l}\text { Protected agriculture and greenhouses in rise } \\
\text { Orange harvest is done seasonally so this favors the } \\
\text { price. } \\
\text { Great cattle production } \\
\text { Technical assistance programs for producers }\end{array}$ & $\begin{array}{l}\text { Small mini } \\
\text { production } \\
\text { Abundant re }\end{array}$ & $\begin{array}{l}\text { h companies are integrated into the } \\
\text { hain of the construction industry. } \\
\text { sources with exploitation potential }\end{array}$ & $\begin{array}{l}\text { Religious centers that attract pilgrims } \\
\text { Great amount of natural resources for tourism }\end{array}$ \\
\hline & $\begin{array}{l}\text { Weakness } \\
\text { es }\end{array}$ & $\begin{array}{l}\text { Insufficient supply of } \\
\text { for agricultural activities } \\
\text { Lack of support for innovative activities } \\
\text { Greater emphasis "in channel" breeding of live } \\
\text { cattle, leaving out the one that adds more value. } \\
\text { Low productivity of cattle due to stallions with } \\
\text { poor genetic load } \\
\text { Low level of association among farmers in the } \\
\text { region. } \\
\text { Insufficient linking of the STI system }\end{array}$ & $\begin{array}{l}\text { The mining } \\
\text { and produc } \\
\text { regarding th } \\
\text { minerals. } \\
\text { Lack of qua } \\
\text { Insufficient }\end{array}$ & $\begin{array}{l}\text { sector is made up of small companies } \\
\text { ers with limited capacities, especially } \\
\text { e analysis, inspection and sampling of } \\
\text { ified technical services } \\
\text { rained human resources }\end{array}$ & $\begin{array}{l}\text { Insufficient roads and communications } \\
\text { infrastructure. } \\
\text { Low level usage of hotel infrastructure } \\
\text { Food services without quality certifications. } \\
\text { Low use of ICTs for the tourism sector. } \\
\text { Seasonality of visits (high and low seasons very } \\
\text { marked). } \\
\text { Pollution of water bodies }\end{array}$ \\
\hline
\end{tabular}

Source: The authors.

\section{Online ISSN: 2385-7137}

http://revistes.ub.edu/index.php/JESB
COPE Committee on Publication Ethics Creative Commons License 4.0@ @creative 


\section{Journal of Evolutionary Studies in Business}

As a result of the analysis of global technology trends, a series of technological boosters and technological platforms were identified to have a good picture on the drivers of technical change in the priority sectors (Table 4).

Table 4. Main technological boosters and technology platforms in the priority sectors

\begin{tabular}{|c|c|c|}
\hline & Technological boosters & Technology platforms \\
\hline AGRI- FOOD & $\begin{array}{l}\text { Integration of agrifood value chain } \\
\text { Differentiation of products for various } \\
\text { consumer segments } \\
\text { Safety and traceability } \\
\text { Reduction of environmental impact and } \\
\text { circular economy }\end{array}$ & $\begin{array}{l}\text { Biotechnology } \\
\text { Nanotechnology } \\
\text { ICTs } \\
\text { Logistics } \\
\text { Smart materials for packaging }\end{array}$ \\
\hline AUTOMOTIVE & $\begin{array}{l}\text { Regulation in safety, energy efficiency } \\
\text { and environmental care. } \\
\text { Digitization of the industry } \\
\text { Change in mobility pattern. } \\
\text { Reduced energy consumption }\end{array}$ & $\begin{array}{l}\text { Advanced materials. } \\
\text { Automation process. } \\
\text { Connectivity, internet of things and } \\
\text { artificial intelligence. } \\
\text { Sensors and nanotechnology. }\end{array}$ \\
\hline LOGISTICS & $\begin{array}{l}\text { Intermodality } \\
\text { Sustainability. } \\
\text { Intelligent transport and storage } \\
\text { systems } \\
\text { Product quality assurance } \\
\text { Time and cost reduction } \\
\text { Security }\end{array}$ & $\begin{array}{l}\text { Smart packaging } \\
\text { Data science and big data, } \\
\text { Sensorial technologies, IoT, artificial } \\
\text { intelligence } \\
\text { Transportation systems } \\
\text { Smart vehicles } \\
\text { Geolocation and communication systems }\end{array}$ \\
\hline MINING & $\begin{array}{l}\text { Operational safety } \\
\text { Environmental sustainability } \\
\text { Productivity and efficiency } \\
\text { extraction } \\
\text { Ultra-deep mining } \\
\text { Social responsibility } \\
\text { Automation }\end{array}$ & $\begin{array}{l}\text { Automation, IoT and artificial intelligence. } \\
\text { Geophysical data modeling } \\
\text { High precision remote sensing } \\
\text { Mobile robotic } \\
\text { Meta data analysis } \\
\text { Environmental engineering } \\
\text { Communication }\end{array}$ \\
\hline CHEMICAL & $\begin{array}{l}\text { Automatization } \\
\text { Emission control and energy } \\
\text { management } \\
\text { Facility Security } \\
\text { Replacement } \\
\text { materials with biological inputs } \\
\text { Search for value-added products } \\
\end{array}$ & $\begin{array}{l}\text { Biotechnology } \\
\text { Nanotechnology } \\
\text { Materials science } \\
\text { Process engineering } \\
\text { Sensors, automation, IoT and artificial } \\
\text { intelligence }\end{array}$ \\
\hline TOURISM & $\begin{array}{l}\text { Economy and human development. } \\
\text { Value Chain Integration } \\
\text { Community and small business } \\
\text { articulation } \\
\text { Environmental sustainability } \\
\text { Leisure management } \\
\text { Intensive use of ICTs }\end{array}$ & $\begin{array}{l}\text { Digitization of services } \\
\text { Applications for mobile devices } \\
\text { Augmented reality } \\
\text { Consumer Science and Customer Service } \\
\text { Software and multimedia development } \\
\text { Communication }\end{array}$ \\
\hline
\end{tabular}

Source: author's elaboration. 


\section{Journal of Evolutionary Studies in Business}

Considering these elements for discussions among actors of the regional innovation ecosystems invited to participate in the workshops to build the RIA, the following areas of innovation were defined as priorities (table 5).

Table 5. Topics of innovation for priority sectors in the four regions

\begin{tabular}{|c|c|c|c|c|}
\hline & ALTIPLANO & CENTRO & MEDIA & HUASTECA \\
\hline AGRI- FOOD & 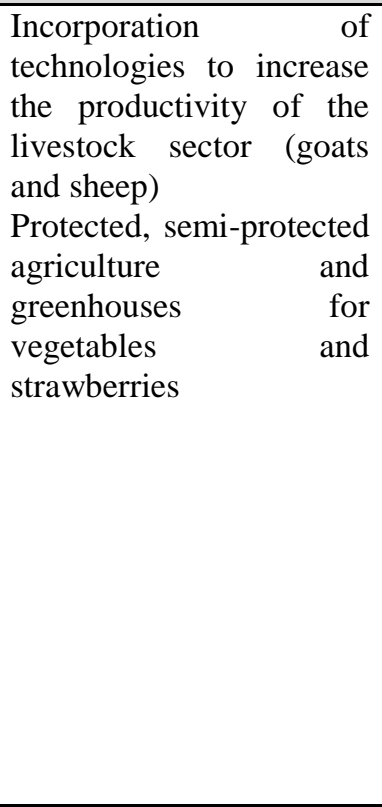 & $\begin{array}{l}\text { Specialized technical } \\
\text { services to support } \\
\text { agro industrial SMEs } \\
\text { Biotechnology applied } \\
\text { to horticultural crops }\end{array}$ & 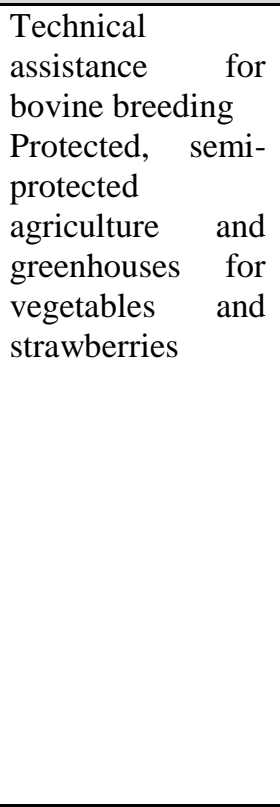 & $\begin{array}{l}\text { Integration of } \\
\text { technologies } \\
\text { for emerging } \\
\text { crops (avocado } \\
\text { and mango) } \\
\text { Improvement } \\
\text { of productivity, } \\
\text { quality and } \\
\text { safety in the } \\
\text { vanilla chain } \\
\text { Improvement } \\
\text { of productivity, } \\
\text { quality and } \\
\text { safety in the } \\
\text { sugarcane chain } \\
\text { (brown sugar). } \\
\text { Reduction and } \\
\text { use } \\
\text { agricultural of } \\
\text { waste }\end{array}$ \\
\hline AUTOMOTIVE & $\begin{array}{l}\text { Management skills } \\
\text { development in suppliers } \\
\text { of the automotive sector } \\
\text { Training, advice and } \\
\text { technical support in } \\
\text { manufacturing 4.0 }\end{array}$ & 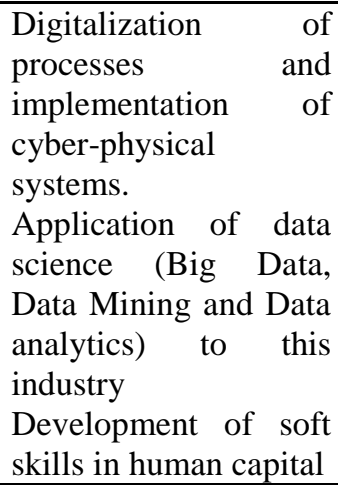 & $*$ & \\
\hline CHEMICAL & $*$ & $\begin{array}{l}\text { Infrastructure to } \\
\text { support innovation } \\
\text { processes of SMEs in } \\
\text { the cosmetic, soap and } \\
\text { personal hygiene } \\
\text { products industry. } \\
\text { Designing and } \\
\text { construction of a pilot } \\
\text { plant to offer services } \\
\text { that support } \\
\text { innovation activities in }\end{array}$ & $*$ & \\
\hline
\end{tabular}




\begin{tabular}{|c|c|c|c|c|}
\hline & ALTIPLANO & CENTRO & MEDIA & HUASTECA \\
\hline & & SMEs & & \\
\hline LOGISTICS & $\begin{array}{l}\text { Training of human } \\
\text { resources for the logistic } \\
\text { sector } \\
\text { National Logistic Node }\end{array}$ & $\begin{array}{l}\text { Super network of } \\
\text { logistic services } \\
\text { San Luis Potosí } 2035 \\
\text { urban and logistic } \\
\text { development master } \\
\text { plan. } \\
\text { SLP airport } \\
\text { Railway station } \\
\text { Interior Custom in } \\
\text { SLP ham } \\
\text { Training of human } \\
\text { resources for the } \\
\text { logistic sector }\end{array}$ & $*$ & \\
\hline MINING & $\begin{array}{l}\text { Equipment and } \\
\text { machinery renovation } \\
\text { and repair center } \\
\text { Strategic Communication } \\
\text { and Social Responsibility } \\
\text { Plan }\end{array}$ & $*$ & $\begin{array}{l}\text { Laboratory of } \\
\text { analytical services } \\
\text { for mining SMEs }\end{array}$ & $*$ \\
\hline TOURISM & $\begin{array}{l}\text { Use of ICTs to promote } \\
\text { cultural tourism } \\
\text { Incorporation of good } \\
\text { practices in the } \\
\text { presentation of tourist } \\
\text { services }\end{array}$ & $\begin{array}{l}\text { Strengthening and } \\
\text { promotion of medical } \\
\text { tourism. } \\
\text { Use of ICTs to } \\
\text { promote the tourism } \\
\text { sector }\end{array}$ & $\begin{array}{l}\text { Good } \\
\text { environmental } \\
\text { and social } \\
\text { responsible } \\
\text { practices } \\
\text { Use of ICTs to } \\
\text { promote tourism }\end{array}$ & $\begin{array}{l}\text { Use of ICTs to } \\
\text { promote } \\
\text { tourism } \\
\text { Training for } \\
\text { tourism service } \\
\text { providers }\end{array}$ \\
\hline
\end{tabular}

Note: $*$ The relevance of these sectors in the regions is low, so projects were not considered. Source: The authors.

During the investigation, priority cross-cutting areas emerged in the four regions and they have motivated the definition of four horizontal lines for innovation projects: social innovation, information and communication technologies (ICT), water management and sustainable energy management.

\section{Analysis of the RIA construction process}

Table 6 summarizes activities and challenges in the different stages of this project. 


\section{Journal of Evolutionary Studies in Business}

Table 6. Considerations for each stage of the Research and Innovation Strategies for Smart Specialization (RIS3), methodology applied to the RIA of SLP, Mexico

\begin{tabular}{|c|c|c|}
\hline Stage & What was done? & Challenges faced \\
\hline $\begin{array}{l}\text { Analysis of the } \\
\text { regional context and } \\
\text { the potential for } \\
\text { innovation }\end{array}$ & $\begin{array}{l}\text { Through the review of quantitative indicators on } \\
\text { economic, social, educational, scientific, and } \\
\text { technological and innovation aspects, the } \\
\text { behavior of the economic sectors and the } \\
\text { productive vocations of the regions were } \\
\text { defined. } \\
\text { Interviews were conducted with key actors in the } \\
\text { priority sectors identified in the State } \\
\text { Development Plan. These interviews helped to } \\
\text { identify areas of specialization based on specific } \\
\text { programs of government agencies or business } \\
\text { groups. } \\
\text { Documentation of the current situation of the } \\
\text { four regions from the STI perspective. }\end{array}$ & $\begin{array}{l}\text { The absence of 'regional' information generated delays in the } \\
\text { integration and analysis of the data, since official sources offer } \\
\text { information only at the state or municipal level. } \\
\text { The data around the innovation activities of universities, R\&D } \\
\text { centers or companies was not available. } \\
\text { Sometimes the 'ideal' actor was not available, so the information } \\
\text { came from other actors with less knowledge of the sector. } \\
\text { It was common to find that the representatives of the different sectors } \\
\text { do not have clarity about concepts associated with STI and, therefore, } \\
\text { they do not know the sector environment. } \\
\text { The definition of priority areas was usually contaminated by } \\
\text { subjective preferences or conflicts of interest from the actors }\end{array}$ \\
\hline $\begin{array}{l}\text { Governance } \\
\text { mechanisms }\end{array}$ & $\begin{array}{l}\text { A State Technical Committee (STC) was } \\
\text { formed, headed by COPOCyT, as well as } \\
\text { regional advisory councils. These councils were } \\
\text { constituted from companies, chambers, } \\
\text { academia and government representatives. } \\
\text { Directories were prepared and done sector by } \\
\text { sector and by region where companies, cluster } \\
\text { leaders, higher education centers, research } \\
\text { centers, experts, representatives of public } \\
\text { government institutions (such as municipal } \\
\text { presidents) and civil society actors (such as } \\
\text { business associations or chambers of commerce) } \\
\text { were considered. } \\
\text { Interviews, industry visits and consensus- }\end{array}$ & $\begin{array}{l}\text { Absence of working groups in the regions that would take internal } \\
\text { responsibility for the construction of RIA. } \\
\text { Limited participation of faculty of institutions belonging to the } \\
\text { working group because they did not assume the project as theirs. } \\
\text { Low level of attendance in some workshops that were mainly due to } \\
\text { three elements: } \\
\text { 1. Low credibility of the institutions, due to the poor results and } \\
\text { expectations generated by the participants in other planning } \\
\text { exercises. } \\
\text { 2. Some actors are unaware of the importance of promoting this } \\
\text { kind of projects and their vision does not go beyond seeking } \\
\text { financial support for their own projects. } \\
\text { 3. The process of convening the workshops (invitation and follow- } \\
\text { up of attendance) was carried out only through electronic }\end{array}$ \\
\hline
\end{tabular}

Online ISSN: 2385-7137

http://revistes.ub.edu/index.php/JESB
COPE Committee on Publication Ethics

Creative Commons License $4.0 @$ creative 


\section{Journal of Evolutionary Studies in Business}

\begin{tabular}{|c|c|c|}
\hline Stage & What was done? & Challenges faced \\
\hline & $\begin{array}{l}\text { building workshops were carried out with key } \\
\text { actors in the regions. } \\
\text { Specialized events were attended in which } \\
\text { contact with relevant actors was privileged. } \\
\text { Validation meetings were held with members of } \\
\text { the STC and with the Regional Advisory } \\
\text { Councils. }\end{array}$ & $\begin{array}{l}\text { communications, which led to confusion about the objective and } \\
\text { importance of the workshops. } \\
\text { It is worth mentioning that there is a small participation of actors } \\
\text { considered from civil society. Most of the participating actors were } \\
\text { firms ( } 46 \text { percent), and members of regional public institutions as } \\
\text { well as research centers and universities ( } 23 \text { percent respectively) } \\
\text { attended in the same proportion. }\end{array}$ \\
\hline $\begin{array}{l}\text { Vision of the future of } \\
\text { the region through } \\
\text { alignment with } \\
\text { national or state } \\
\text { development plans }\end{array}$ & $\begin{array}{l}\text { The initial guidelines of the project were aligned } \\
\text { to the State Development Plan (2015-2021) as } \\
\text { well as to the Sectorial Program for Economic } \\
\text { Development (2016-2021). } \\
\text { Agreement was reached with the Regional } \\
\text { Advisory Councils on the areas of specialization } \\
\text { Coordination with COPOCyT to boost the } \\
\text { common vision was essential }\end{array}$ & $\begin{array}{l}\text { Currently, México is going through a process of political change that } \\
\text { has generated uncertainty around new national policies of STI. } \\
\text { There is little institutional credibility } \\
\text { Political differences and manifestation of conflicts of interests in the } \\
\text { workshops } \\
\text { Little familiarity of some ecosystem actors with technological trends } \\
\text { and future challenges } \\
\text { Lack of a shared vision of 'region' that limits the systemic approach. }\end{array}$ \\
\hline 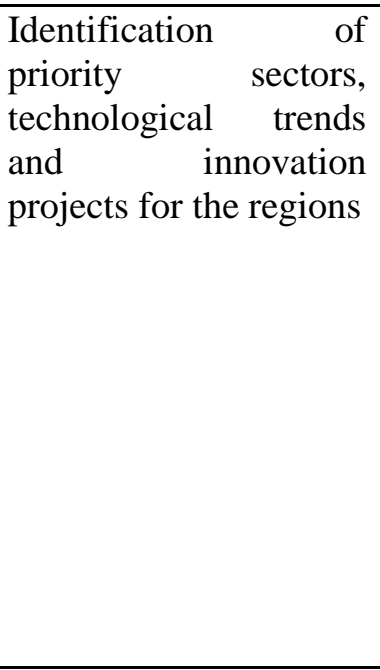 & $\begin{array}{l}\text { Studies of technological trends were used to } \\
\text { familiarize participants in the workshops with } \\
\text { the most relevant changes and innovations that } \\
\text { may be presented in the next ten years on each } \\
\text { sector. } \\
\text { Workshops for each area of specialization of the } \\
\text { different regions were carried out. }\end{array}$ & $\begin{array}{l}\text { Little knowledge of the actors about the concept of innovation and } \\
\text { technological trends. } \\
\text { Defense of traditional positions against technological changes. } \\
\text { Participating key actors, brought their own work agendas, so they } \\
\text { sought to align innovation projects to their particular interests or } \\
\text { those of their industry. When this happened, other actors without so } \\
\text { much bargaining power, limited their own participation, so that in the } \\
\text { consensus exercises, specific groups' opinion prevailed. } \\
\text { Representatives of academic groups interpreted this exercise as an } \\
\text { opportunity to obtain resources for research projects that do not } \\
\text { impact the areas of specialization } \\
\text { Some workshop participants maintained a passive attitude, mainly } \\
\text { due to lack of knowledge. } \\
\text { In some areas of specialization there was indifference of industry } \\
\text { representatives }\end{array}$ \\
\hline
\end{tabular}

\section{Online ISSN: 2385-7137}

http://revistes.ub.edu/index.php/JESB
COPE Committee on Publication Ethics

Creative Commons License 4.0@Creative 


\section{Journal of Evolutionary Studies in Business}

doi.org/10.1344/JESB2020.1.j069

\begin{tabular}{|c|c|c|}
\hline Stage & What was done? & Challenges faced \\
\hline $\begin{array}{l}\text { Definition of list of } \\
\text { projects, road maps } \\
\text { and action plans. }\end{array}$ & $\begin{array}{l}\text { Considering all the information from the } \\
\text { previous stages, a list of innovation projects was } \\
\text { built for the areas of intelligent specialization, } \\
\text { which resulted in a portfolio of innovation } \\
\text { projects with a multiplier positive effect in the } \\
\text { regions. } \\
\text { Project documents that include the strategy to } \\
\text { execute them were developed as well. } \\
\text { Presentation and validation of the project } \\
\text { portfolio and the execution strategy by the STC } \\
\text { and the regional advisory councils. }\end{array}$ & $\begin{array}{l}\text { Difficulty in translating the needs of the sectors and the problems of } \\
\text { the regions into innovation projects, since the causes of these } \\
\text { problems are not of technological nature. } \\
\text { Low participation of actors from the regions in the elaboration of the } \\
\text { projects. } \\
\text { Uncertainty about funding sources and mechanisms for projects due } \\
\text { to the lack of definition regarding CONACYT programs and other } \\
\text { federal agencies that provide support for innovation. } \\
\text { Difficulty in identifying project's leaders, especially in those areas in } \\
\text { which actor's industry had indifference to these exercises }\end{array}$ \\
\hline $\begin{array}{l}\text { Integration } \\
\text { monitoring } \\
\text { evaluation } \\
\text { mechanisms. }\end{array}$ & $\begin{array}{l}\text { Design of an execution plan and creation of } \\
\text { public policy recommendations, in order to } \\
\text { establish incentives for project implementation. } \\
\text { Dissemination of regional agendas. } \\
\text { Definition of indicators and monitoring } \\
\text { procedures. }\end{array}$ & $\begin{array}{l}\text { Obtaining the commitment of the different areas of the state } \\
\text { government for the execution of the agendas. } \\
\text { Insufficient budgets for execution. } \\
\text { The agendas will be widely disseminated; if they are not translated } \\
\text { into concrete actions, the actors (especially the industry) will have a } \\
\text { very negative reaction to this type of innovation plans. } \\
\text { COPOCyT shall carry out the monitoring of the execution in } \\
\text { accordance with the proposed indicators, based on its own Regional } \\
\text { Councils of Science and Technology (CORECYT). }\end{array}$ \\
\hline
\end{tabular}

Source: The authors.

COPE Committee on Publication Ethics

Creative Commons License 4.0 @ @creative 
One of the greatest challenges facing the application of RIS3 concerns regions with very limited innovation-related assets. In the case of SLP, some regions contain no research institutes and yet have only a very limited capacity for developing an innovation system, constrained by institutional and governance issues as well as by technological issues. For that reason, it is essential to consider that innovation policy orientation and the policy instruments have to be different to adapt them to diverse contexts, exactly as smart specialization argues, and the use of indicators for ex ante policy design, policy experimentation and better ex post evaluation are essential (Veugeleurs 2015).

In the case of the four regions of SLP, the challenges of the application of RIS3 for the construction of RIA are those of a regional innovation system with an institutional framework that is concentrated in the Centro Region. The other three regions lack institutional capabilities (both at the public sector as well as among the private actors) and this presents a great challenge to conduct discussions with representatives of priority sectors that are not used to manage science and technology concepts and information. RIS actors have also a poor perception of policies and available capabilities to foster long term innovation projects.

\section{Analysis of the application of RIS3 for the definition of RIA in SLP}

\section{The process of creating the RIA}

A critical element for the elaboration of RIAs has been to follow a logical sequence in accordance with the methodological approach of RIS3. It has been very helpful that the State Development Plan of SLP proposes a set of priority areas of development in the regions, which is a good starting point. However, the application of this approach in a country like Mexico, with very heterogeneous regions is complex for several reasons. The first of these, is the low availability of socioeconomic information in the regions. The state of SLP has made a 
remarkable effort to have reliable statistical information, but this is added at the state level. This forced the working group to generate and, in some cases, estimate regional data, causing delays in the process and the challenge of sharing this information with the participants in the workshops, in order to counteract another difficulty that lies in the unequal level of knowledge that representatives of the sectors have. The latter is very relevant because, in order for the consultation spaces to be implemented successfully, it is necessary that the participants have sufficient and precise information on the socioeconomic conditions and technological trends in their sector. In this case, the coordinating team had to carry out the basic studies and disseminate them, although due to the pressure of time, it was not possible to verify that the participants in the workshops had adequately understood the content of the reports. With no doubt, that is an aspect to improve.

The translation of the proposals emanating from the workshops into concrete innovation projects is not a simple matter. We must point out that the participants presented a general idea that needs to be worked out in such a way that clear objectives, technical and economic justification, expected results, strategy, possible executors, the necessary budget and the way to finance the project. Therefore, it is necessary to have a work team who has experience in the building of innovation proposals as well as a guide to have a homogeneous structure in the portfolio. For this purpose, it was agreed to develop a template that follows the Mexican Standard of Technological Projects.

The conduction of the workshops is critical to generate useful results, especially taking into account that it is usual that some people seek to lead the discussions towards their particular agenda. Therefore, meetings should be coordinated by facilitators with experience and knowledge about the process of consensus building. 


\section{RIA governance}

Governance refers to a new arrangement of authority and power where actors make decisions and generate policies that are binding as noted by Hanf and Jansen (1998). Accordingly, to this, the construction of the RIA requires the planning of spaces for representatives to participate (companies, knowledge generating institutions, government and society). Therefore, the constitution of regional advisory councils has been a basic component to involve such representatives.

The project coordinating group was responsible for identifying opinion leaders belonging to the cited sectors and convening them, taking advantage of the fact that RIA creation started at the highest level of the state government. Thus, in the four regions, representative groups with a high level of influence were integrated, although they do not always have mastery of innovation issues.

During the process, COPOCyT structured additional regional STI councils, the so-called CORECYT. At the beginning, there was some confusion and overlap between the activities of the regional advisory councils and the CORECYTs, especially considering that there were several members common to both figures. That is why we sought to coordinate the actions with both groups and this proved to be an adequate decision for the continuity and monitoring of RIA activities, since the CORECYT has an institutional structure that does not depend on this project.

The federal government would have an important role in the governance of the project, hence CONACyT is its co-sponsor. However, the change of government in December 2018 caused an element of uncertainty, since the new CONACYT's authorities have questioned the project and the process, which has limited their participation as a policy-generating body in the 
matter. This, without a doubt, is an important gap that imposes the need to negotiate with CONACyT in order to reach a commitment to the implementation of RIAs, since it is the organization that manages the largest budget to finance STI projects.

\section{Working group for the elaboration of RIA}

The working group has been coordinated by an academic person from the most important public university in SLP, whom has had an excellent network of relationships in the regions and in most of the priority sectors. Likewise, the leadership of a university with presence and recognition throughout the state can be considered as an important asset for the project, as it provides credibility and convening power.

In the group of collaborators there have been specialists with experience in other RIS3 exercises, which allowed the process to be carried out more expeditiously, although not without the difficulties mentioned.

Two other universities joined the group, but their participation was rather small. This has been a limitation since such a complex project with activities distributed over a large and diverse territory requires competent and committed human resources. This proves the need to have a better structure of the working team to achieve greater efficiency. Moreover, collaboration with specialists from the regions is an element that should be strengthened in order to enhance the process of analyzing specific socioeconomic contexts with sound qualitative information that is essential for the definition of areas of smart specialization and priority projects.

The coordination of the work of this group with COPOCyT has been fundamental to achieve synergy and to generate the message that the process of elaboration of the RIA relates to the decision-making bodies regarding STI. 


\section{Final considerations}

It is important to note that when working with heterogeneous and disarticulated innovation systems such as the ones of the SLP regions, the challenges around building consensus are substantial. That is why emphasis is placed on the formation of a solid governance framework and fieldwork as fundamental elements. The interviews, with companies and key stakeholders, and discussion workshops are key to understanding the potential and needs of the regions, as well as the expectations of stakeholders.

For this, timely planning and convening of actors is essential. It has been clear that a public relations strategy has to be designed to increase the convening power and the organization required to have key agents involved in the workshops and governance meetings. Having the support of an institution with leadership in the region, such as COPOCyT, improves and simultaneously strengthens the commitment of the actors with the process and RIA.

The key actors, who are also opinion leaders, become a very effective catalyst for the different stages of the project. Therefore, this selection deserves special attention. In this project, such actors emerged from different institutional areas, as some are in municipal governments, others in companies, consulting firms or industrial chambers.

Executing the RIA will pose another major problem: financing. Due to the instability and uncertainty in the institutional framework dedicated to supporting STI, there is a need to raise awareness among the different actors on the RIAs and on searching alternative sources of funds for the execution of the project portfolio.

We agree with McCann and Ortega (2016) that RIS3 is not a one-off process, necessary simply to respond to ex ante conditionalities, but rather an ongoing process of governance and policy- making upgrading. It is therefore that SLP's authorities must institutional framework 
that is concentrated in the Centro Region. The other three regions lack institutional capabilities (both at the public sector as well as among the private actors) and this presents a great challenge to conduct discussions with representatives of priority sectors that are not used to manage science and technology concepts and information. Considering this agendas require careful monitoring and stability in the governance structure; this could be achieved if the Regional Science and Technology Councils are strengthened.

This RIS3 study has had the benefit of giving stakeholders a good information base to understand some aspects of innovation that can be fundamental for local development. Involving public and civil society actors as well as private-sector actors has been a very important milestone to increase collective learning on the state and potential of the regions to foster an innovation-based growth.

\section{References}

Abas, Muhamad. 2019. "Public Policy and Governance: Theory and Practice." In Global Encyclopedia of Public Administration, Public Policy, and Governance, edited by A. Farazmand, 1-7. Switzerland: Springer Nature.

Barca, Fabrizio, McCann Phillip, and Andrés Rodríguez -Pose. 2012. "The case for regional development intervention: place-based versus place-neutral approaches." Journal of Regional Science 52:134-152.

Barroeta Belén, Javier Gómez Prieto, Jonatan Paton, Manuel Palazuelos, and Marcelino Cabrera Giráldez. 2017. Innovation and regional Specialisation in Latin America. Luxembourg: European Commission. https://ec.europa.eu/jrc/sites/jrcsh/files/innovation_and_regional_specialisation_latinoa merica.pdf

Cassiolato, José Eduardo, Marcelo Pessoa de Matos, and Helena Lastres. 2013. "Innovation systems and development." In International Development: Ideas, Experience, and Prospects, edited by Bruce Currie-Alder, Ravi Kanbur, David M. Malone, and Rohinton Medhora. London: Oxford Scholarship. 
Checkland, Peter. 1999. Systems Thinking, Systems Practice: Includes a 30 Year Retrospective. UK: John Wiley \& Sons Ltd.

Consejo Nacional de Ciencia y Tecnología, CONACYT. 2015. "Agenda Estatal de Innovación de San Luis Potosí." Last modified October 21, 2019. http://www.agendasinnovacion.org/?p=969

Cooke, Philip. 1998. “'Regional innovation systems-an evolutionary approach.” In Regional Innovation Systems. The Role of Governance in a Globalized World, edited by Philip Cooke, Martin Heidenreich, and Hans-Joachim Braczyk. London: UCL Press.

Cooke, Philip, Mikel Gomez, and Goio Uranga. 1997. "Regional innovation systems: institutional and organisational dimensions." Research Policy 26:475-491.

Del Castilli, Jaime, and Jonatan Paton. 2013. "Las estrategias regionales de innovación y especialización inteligente (RIS3), nueva etapa de la política regional Europea en el apoyo a la innovación empresarial." Journal of Public Policies and Territories 4:17-23.

Dutrenít, Gabriela. 2009. "Introduction.” In Sistemas regionales de innovación: un espacio para el desarrollo de las PyMES. El caso de la industria de maquinados industriales, coordinated by Gabriela Dutrenít. Mexico: Universidad Autónoma Metropolitana.

Flanagan, Kieron, Elvira Uyarra, and Manuel Laranja. 2011. "Reconceptualising the "policy mix' for innovation.” Research Policy 40(5): 702-713.

Foray, Dominique, John Goddard, Xabier Goenaga, Mikel Landabaso, Philip McCann, Kevin Morgan, Claire Nauwelaers, and Raquel Ortega-Argilés. 2012. "Guide to Research and Innovation Strategies for Smart Specializations (RIS 3)." Regional Policy European $\begin{array}{lllll}\text { Commission. } & \text { Last } & \text { April } & \text { 12, }\end{array}$ https://ec.europa.eu/regional_policy/sources/docgener/presenta/smart_specialisation/sm art_ris3_2012.pdf

Foster, John. 1993. "Economics and the Self-Organization Approach: Alfred Marshall Revisited.” The Economic Journal 103 (419): 975-991.

Foster, John. 2005. "From Simplistic to Complex Systems in Economics." Cambridge Journal of Economics 29 (6): 873-892.

Goméz Prieto, Javier, and Patrice Dos Santos. 2017. Smart Specialisation in EU and Chile, challenges and opportunities. Smart Specialisation. Luxembourg: European Commission. 
Government of San Luis Potosí. 2012. "Plan Estatal de Desarrollo 2009-2015.” Last modified June 8, 2019. https://slp.gob.mx/sitionuevo/DocumentosPLAN/plan2016_eje1.pdf

Graham John, Amos Bruce, and Tim Plumptre. 2003. Principles for good governance in the 21st century. Ottawa: Institute of Governance.

Hanf, Kenneth, and Jansen Alf-Inge. 1998. Governance and Environment in Western Europe. Politics, Policy and Administration. London: Routledge.

Höglund, Linda, and Gabriel Linton. 2017. "Smart specialization in regional innovation systems: a quadruple helix perspective.” R\&D Management 48 (1): 60-72.

Instituto de Investigaciones Legislativas, IIL. 2016. "Ley de planeación del estado y municipios de San Luis Potosí." Last modified October 21, 2019. https://sanluis.gob.mx/wp-content/uploads/2015/12/Ley-de-Planeacion-del-Estado-yMunicipios-de-San-Luis-Potos--.pdf>

Instituto Nacional de Estadística y Geografía, INEGI. 2018. "Producto Interno Bruto y Cuentas Nacionales." Last modified October 21, 2019. https://www.INEGI.org.mx/temas/pib/

Kroll, H. 2015. "Efforts to implement smart specialization in practice - leading unlike horses to water." European Planning Studies 23 (10): 2079-2098.

Lewin, Kurt. 1958. "Group Decision and Social Change.” In Readings in Social Psychology, edited by E.E Maccoby, T.M Newcomb and E.L Hartley. New York: Holt, Rinehart and Winston.

Lundvall, Bengt-Ake. 1992. National Systems of Innovation. Towards a Theory of Innovation and Interactive Learning. London: Printer Pub.

McCann, Philip, and Raquel Ortega. 2016. "Smart Specialisation: Insights from the EU Experience and Implications for Other Economies." Journal of Regional Research $36: 279-293$.

Mejía, Olivia, José Solleiro, Moisés García, and Rosario Castañón. 2019. Capacidades productivas y de innovación en las 4 regiones de San Luis Potosí. México: UASLP.

Morchain, Daniel, Dian Spear, Gina Ziervogel, Hillary Masundire, Margaret Angula, Julia Davies, and Salma Hegga. 2019. "Building transformative capacity in southern Africa: Surfacing knowledge and challenging structures through participatory vulnerability and risk assessments." Action Research 17(1): 1941. 
Morisson, Arnault, and Mathieu Doussineau. 2019. "Regional innovation governance and place-based policies: design, implementation and implications." Regional Studies, Regional Science 6 (1): 101-116.

Perry Beth, and Tim May. 2007. "Governance, Science Policy and Regions: An Introduction.” Regional Studies 41 (8): 1039-1050.

ProMéxico. 2017. "Mapa de exportaciones de México. Exportaciones de San Luis Potosí." Last modified August 17, 2019. http: // mem. promexico.gob.mx/info_estatal.jsp

Rózga, Ryszard, and José Solleiro. 2017. Sistemas regionales de innovación como instrumento de la política pública de innovación. Mexico: UAM - Juan Pablos Editor.

Safarzyska, Karolina, and Jeroen Van den Bergh. 2010. "Evolutionary models in economics: a survey of methods and building blocks." Journal of Evolutionary Economics 20 (3): 329-373.

Silverberg, Gerald, Giovanni Dosi, and Luigi Orsenigo. 1988. "Innovation, Diversity and Diffusion: a Self-Organization Model.” Economic Journal 98 (393): 1032-1054.

Sistema de Información Agroalimentario y Pesquero, SIAP. 2018. "Atlas Agroalimentario 2012-2018." Last modified August 2019. https://nube.siap.gob.mx/gobmx_publicaciones_siap/pag/2018/Atlas-AgroalimentRIAo2018.

Veugeleurs, Reinhilde. 2015. Do we have the right kind of diversity in innovation policies among EU Member States?. Vienna:WWWforEurope. https://www.econstor.eu/bitstream/10419/125763/1/WWWforEurope_WPS_no108_MS 228.pdf

This is an Open Access article distributed under the terms of the Creative Commons Attribution-Non-Commercial-No Derivatives License (http://creativecommons.org/licenses/by-nc-nd/4.0/), which permits non-comercial re-use and distribution, provided the original work is properly cited, and is not altered or transformed in any way. 